\title{
Multi-Reservoir Optimization for Maximization of Releases for Hydropower Generation Considering Environmental Flow
}

\author{
Pushpak D. Dabhade, Dattatray G. Regulwar \\ Department of Civil Engineering, Government College of Engineering, Aurangabad, India \\ Email: pushpak3dabhade@gmail.com,regulwar@gmail.com
}

How to cite this paper: Dabhade, P.D. and Regulwar, D.G. (2021) Multi-Reservoir Optimization for Maximization of Releases for Hydropower Generation Considering Environmental Flow. Journal of Water Resource and Protection, 13, 931-944. https://doi.org/10.4236/jwarp.2021.1312050

Received: October 24, 2021

Accepted: December 3, 2021

Published: December 6, 2021

Copyright $\odot 2021$ by author(s) and Scientific Research Publishing Inc. This work is licensed under the Creative Commons Attribution International License (CC BY 4.0).

http://creativecommons.org/licenses/by/4.0/

(c) (i) Open Access

\begin{abstract}
Water is the soul of the world. It is the most important element for the survival of humans, animals, birds, plants and all other living things on earth. Water is essential for the beginning of life as well as regular availability of water ensuring the survival, growth and overall nourishment. Thus, proper planning and use of reservoir water are essential for all. To tackle this issue different optimization techniques underline their need and importance in the reservoir operations. In the present study, multi-reservoir optimization model is developed using Python programing language considering the objective of maximization of total annual release for hydropower generation. Model is applied to 3 reservoirs from Godavari River basin from Maharashtra state India. Water essential for conservation of environment has also been made available in river as environmental flow as per the recommendations of Central Water Commission (CWC) India. Developed optimization model provides optimal monthly operation policies.
\end{abstract}

\section{Keywords}

Optimization, Multi-Reservoir, Reservoir Operation, Environmental Flow, Linear Programming

\section{Introduction}

Availability of rainfall has declined due to climate change in recent times and so the emphasis is on storing more water in reservoirs. Through this storage, man is only engaged in his own development, but the water required for the biodiversity and the nature as a whole, which grows and depends on the river water, is not available. An example of this is the river bed that dries up during the 
non-monsoon season in India. Most of the rivers in Maharashtra have to face this crisis every year. In case of Godavari River basin which is situated at Maharashtra State of India, similar situation is experienced in Marathwada region many days of the year. On the other hand, demand for electricity is also high due to increasing industrialization and development works. While electricity is being generated from conventional power plants to meet the demand, a huge number of natural resources are being used and pollution is also increasing. Due to this increased pollution, global temperature is constantly rising. Also, global warming further becomes cause of changes in nature, causing problems of erratic rainfall. It is necessary to take timely steps to get out of all this vicious cycle. For this, it is necessary to adopt a balanced policy of sustainable development.

Electricity generation from non-conventional sources also promotes sustainable development as they do not cause environmental pollution. The hydropower plant is a good example of this. Power generation by hydropower plants does not deplete any natural resources and also curbs pollution. In this paper, an attempt has been made to present an optimal operation policy for multi-reservoirs considering the objective of maximization of the hydropower generation from the Jayakwadi Stage-I dam constructed at Paithan, Jayakwadi Stage-II situated at Majalgaon and Yeldari reservoir constructed at Yeldari from Godavari River basin. Additionally study also aims to maintain the minimum essential environmental flow conditions relative to the Central Water Commission (CWC) India recommendations to preserve the river's ecosystem.

Labadie [1] has presented a review on optimal operation model for multi-reservoir systems by all different methods of optimization for water resources operations and management. Wurbs [2] has discussed different reservoir-system simulation and optimization models to give guideline about different methods and its usefulness in various types of decision-support situations. Kim et al. [3] have developed a monthly operating rule for single-reservoir operation for Soyanggang dam basin in Korea Peninsula, with objectives of minimization of shortage and maximization of sum of Hydropower production. The simulation results are obtained by using the developed piecewise-linear operating rule. Chen et al. [4] have suggested an interactive dynamic programming model for optimizing reservoir operation to support the policy makers for balancing humans and environmental water requirement. Mousavi et al. [5] have presented reservoir operation model using a dynamic programming fuzzy rule-based approach. This model was applied to the reservoirs system in Iran. Developed model gives better values of the simulated objective function with the higher reliability of meeting the demand. Nagesh Kumar et al. [6] have developed a reservoir operation model for flood control purpose with the help of folded dynamic programming. Regulwar and Anand Raj [7] have proposed a multi-reservoir operation model using genetic algorithm under fuzzy environment considering multi-objectives. Regulwar and Kamodkar [8] derived a fuzzy constrained reservoir operation model for multipurpose reservoir. Model is useful in dealing with imprecise constraints. Jager and Smith [9] presented a review of the 
hydropower generation study along with ecosystem conservation. The study suggests three measures required for environmental sustainability while planning for reservoir operations. It advised to carry out research to determine the characteristics of flow difference necessary for the health of the river, develop an assessment method to assess river health and develop a software that predicts water balance and its effects on ecosystem. Ju-Hwan [10] has suggested an optimization model by linear programming for maximization of hydropower generation as an alternative to nonlinear model. Arunkumar and Jothiprakash [11] have developed a non-linear programming model for optimal reservoir operation for hydropower generation. In the study this hydropower generation in three different seasons was analyzed for different dependable flow conditions. Morankar et al. [12] presented integrated approach for multi-objective fuzzy optimization for planning of sustainable irrigation by fuzzification of objectives of maximization of net benefits, crop production and labor employment. Jothiprakash and Arunkumar [13] have presented optimization model developed for maximization of the hydropower production in multiple hydropower plants using a non-linear programming for multi-reservoir system. Aboutalebi et al. [14] have derived monthly operating optimal reservoir operation rules for hydropower generation with support vector regressions and nondominated sorting genetic algorithm (SVR-NSGA). The main advantage of SVR-NSGAII is its ability to determine the various combinations of parameters and variables that are useful for reservoir operators to optimize reservoir releases. Ghimire \& Reddy [15] have presented Particle Swarm Optimization (PSO) technic based optimal reservoir operation policy for hydropower generation using and sustainability analysis. In this study weekly operated model was developed for Upper Seti hydropower reservoir system in Nepal for maximization of annual hydropower production. Rahimi et al. [16] have elaborated monthly operating model developed for simultaneous optimization of hydropower energy and flood control for multi-reservoir system using imperialist competitive algorithm. Objective considered for study is to increase revenue generation from hydropower and also control the flood situations for the Ostour and Pirtaghi reservoirs of Iran.

Environmental Flow: Brisbane declaration [17] provided a clear idea of Environmental Flow (E-Flow) and it can be defined as "The quantity, timing, and quality of water flows required to sustain freshwater and estuarine ecosystems and the human livelihoods and wellbeing that depend on these ecosystems." This declaration was formulated in 2007 during the 10th International River Symposium and International Environmental Flows Conference held in Brisbane, Australia, with participation of delegates from more than 50 countries. Jain and Kumar [18] have highlighted Indian scenario of environmental flow assessment with different Indian River case studies. Lokgariwar et al. [19] have discussed a case study of Upper Ganga River cultural water requirements for environmental flow assessment. S.K. Jain [20] has suggested adaptive management of environmental flow, which involves estimation of environmental flow requirements, the consideration of those requirements in reservoir operation poli- 
cies and monitoring the results after implementation to revise the estimation.

Indian scenario: The Indian summer monsoon typically lasts from June - September with large areas of western and central India receiving more than $90 \%$ of their total annual precipitation during the period, and southern and northwestern India receiving $50 \%$ to $75 \%$ of their total annual rainfall. These trends increase the tendency to store more water in reservoirs during this season to make it available for remaining period of the year. It also affects the availability of base flow in river throughout the year. In most of the rivers no flow condition is observed during many days in non-monsoon season because of shortage of rainfall and the storage made by upstream reservoirs. Such situation degraded the river ecosystem badly and need a sustainable approach to make minimum flow available for all seasons.

Recommendation by Central Water Commission (CWC) [21]: To address the issue of Environmental flow in India Central Water Commission in 2007 carried out studies on minimum flows in various Indian rivers: Himalayan Rivers such as the Bhagirathi, Alaknanda; and other rivers in the Krishna and Godavari basins, and southern tributaries of the Yamuna and Tapi. The studies show that, in the case of Himalayan rivers due to snow melting from different Himalayan glaciers availability, natural flows are very high. Despite this situation, it's not possible to preserve such high availability of water at lower reaches due to high amount of water requirements. CWC recommends environmental flow conditions for Himalayan Rivers thus: The minimum environmental flow should not be less than $2.5 \%$ of the $75 \%$ dependable annual flow. Also, a flushing flow with a peak flow of not less than $250 \%$ of the $75 \%$ dependable annual flow is required during the monsoon period. For areas other than Himalayan rivers, the recommendations are: The minimum environmental flow must not be less than $0.5 \%$ of the $75 \%$ dependable annual flow. Also, a flushing flow with a peak flow of not less than $600 \%$ of the $75 \%$ dependable annual flow is required during the monsoon period.

In October 2018 Central Government circulated a notification regarding minimum environmental flows requirements in Ganga [22] which has to be maintained at downstream of different projects constructed for diversion of river flows for different purposes like irrigation, hydropower, domestic and industrial and other needs. The order of e-flows is applicable to the upper Ganga River basin starting from the originating glaciers to Unnao district of Uttar Pradesh. The requirement of minimum environmental flows is applicable to all the existing, under-construction and future projects. For the existing projects a period of three years is given to ensure minimum environmental flow which is unable to meet the CWC norms at present.

Government of Maharashtra Water Resources Department published a report on Integrated State Water Plan for Maharashtra [23] about importance of water for eco-system it describes river, water sources, aquifers and wetlands which will be regarded as natural systems and must be protected from overuse, extinction, 
pollution. In consultation with experts, stake holders and NGO essential steps shall be planned like preparation of annual action plan by incorporating necessary environment flow for restoration and maintenance of river health.

After reading all the above studies, it was found that required quantity of environmental flow releases should be estimated and incorporated in reservoir operation model to achieve a sustainable development policy in reservoir planning. In present study from the past inflow data, it has been observed that availability of inflow in Godavari basin is insufficient to provide flushing flow from reservoirs during the monsoon, also no flow condition has been observed in river during many days of year. It shows inability to satisfy both minimum required environmental flow release conditions recommended by CWC, so the first condition of a flushing flow of not less than $600 \%$ of the $75 \%$ dependable annual flow is not feasible to adopt. In present model, condition of $0.5 \%$ of the $75 \%$ dependable annual flow is considered as release for environmental flow and provided constant for all months.

\section{System Description}

Godavari is an important river in India. Godavari originates at Tryambakeshwar in Nashik district of Maharashtra state. It flows through Marathwada region Godavari passes Aurangabad, Beed, Parbhani and Nanded districts. Godavari is the lifeline of this region with its great religious significance. For this study Jayakwadi Stage-I (P1), Jayakwadi Stage-I (P2) and Yeldari (P3) projects were considered as shown in Table 1. Jayakwadi Stage-I (P1) is a biggest multipurpose project constructed on Godavari at Paithan in Aurangabad district. Jayakwadi Stage-II (P2) is the component of Jayakwadi Stage-I and constructed on river Sindaphana tributary of Godavari at Majalgaon in Beed district. Third project is Yeldari reservoir (P3) on river Purna in Parbhani district.

Jayakwadi Stage-I (P1) and Jayakwadi Stage-II (P2) projects are multipurpose reservoirs which releases water for different purposes like Irrigation supply, supply for hydropower generation, drinking water supply etc. Similarly, Yeldari (P3) project releases water mainly for the purpose of hydropower generation through installed hydropower plant of capacity 15 MW. Figure 1 shows location sketch of all hydropower plants.

\section{Model Development}

Study aims to develop optimization model to maximize the total annual releases

Table 1. Details of hydropower plants.

\begin{tabular}{ccccc}
\hline Sr. No. & Project Name & River & Project Type & $\begin{array}{c}\text { Installed Hydropower } \\
\text { Plant Capacity (MW) }\end{array}$ \\
\hline 1. & Jayakwadi Stage-I & Godavari & Multipurpose & 12 \\
2. & Jayakwadi Stage-II & Sindaphana & Multipurpose & 2.25 \\
3. & Yeldari & Purna & Hydropower & 15 \\
\hline
\end{tabular}




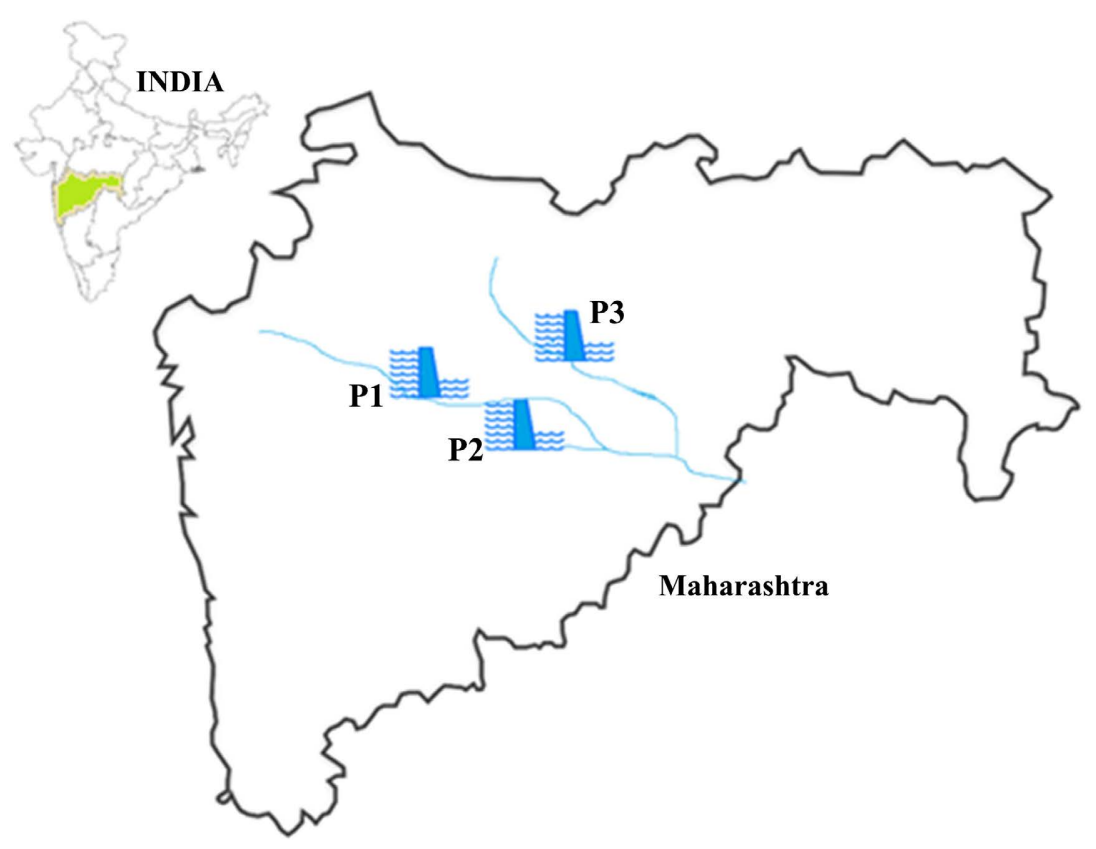

Figure 1. Sketch showing location of hydropower plants.

for hydropower production (i.e., HPR) through the installed hydropower plants from Jayakwadi stage-I, Jayakwadi stage-II and Yeldari project. At the same time, the demand for release of water for other purposes like irrigation, drinking water supply etc. has also been taken into consideration. Additionally, the environmental flow essential at downstream side of respective reservoirs were also estimated and made available throughout the year as per CWC recommendations.

Thus, objective function can be expressed as follows:

Maximization of total annual release for Hydro-Power generation (HPR)

$$
\max Z=\sum_{t} \sum_{t}(\mathrm{HPR})_{i t} \quad \forall i=1,2,3 ; \forall t=1,2,3, \cdots, 12
$$

where, $i$ denotes the number of reservoirs and $t$ represents the number of time step. Optimization model involves total of three reservoirs. Objective function is subject to some constraints as follows:

\subsection{Irrigation Release}

Irrigation supply is provided from Jayakwadi Stage I \& II reservoirs for the irrigable command area of around 2355.25 square kilometer combined. Accordingly, for all reservoir irrigation releases (IRR) must be less than or equal to maximum irrigation demand (Max_IRD) for all time period. Similarly, irrigation water supply must be greater than or equal to minimum irrigation demand (Min_IRD). This irrigation release constraint is given by:

$$
\text { Min_IRD } D_{(i, t)} \leq \operatorname{IRR}_{(i, t)} \leq \operatorname{Max} \_I R D_{(i, t)} \forall i=1,2,3 ; \forall t=1,2,3, \cdots, 12
$$

\subsection{Turbine Capacity Constraints}

Constraints for turbine release are considered according to capacity of turbine 
installed in power house for hydro-power production. The water release for power production (HPR) should be less than or equal to maximum capacity of turbine (TC) for all month. Also, the water releases for hydro-power production for all month should be greater than or equal to the firm power (FP) requirement. Mathematically these constraints are given by:

$$
\begin{aligned}
\operatorname{HPR}_{(i, t)} \leq \mathrm{TC}_{(i)} & \forall i=1,2,3 \\
\operatorname{HPR}_{(i, t)} \geq \mathrm{FP}_{(i)} & \forall t=1,2,3, \cdots, 12
\end{aligned}
$$

\subsection{Storage Capacity of Reservoir}

Reservoir storage (RS) for all months should be less than or equal to the maximum reservoir storage capacity (Max_RSC) of the reservoir and should be greater than or equal to Minimum Storage Capacity (Min_RSC) of the reservoir. It can be given as:

$$
\operatorname{Min} \_R S C_{(i)} \leq \mathrm{RS}_{(i, t)} \leq \operatorname{Max} \_R S C_{(i)} \forall i=1,2,3 ; \forall t=1,2,3, \cdots, 12
$$

\subsection{Environmental Flow Release}

Environmental flow is essential to preserve the river health and river ecosystem and must be considered in reservoir planning. Environmental flow (EFR) required for Godavari sub basin is also considered. Relative to the CWC study report guidelines it is suggested that the quantity of minimum environmental flow should be taken as $0.5 \%$ of $75 \%$ dependable annual flow. The quantity of environmental flow is estimated in reference to the recommendations of CWC and written as.

$$
\begin{aligned}
& \operatorname{EFR}_{(i, t)}=0.5 \% \text { of } 75 \% \text { Dependable annual flow } \\
& \forall i=1,2,3 ; \forall t=1,2,3, \cdots, 12
\end{aligned}
$$

\subsection{Constraint of Hydrologic Continuity}

Hydrologic continuity constraints deal with release from turbine (HPR), release for irrigation (IRR), a constant value for drinking water supply release (WSR) and release of environmental flow (EFR) is taken, storage of reservoir (RS), inflows (IN), different losses from the reservoirs like loss due to evaporation for all months. Also overflow (OVF) from spillway can be observed for some time period. The individual hydrologic continuity constraint for each reservoir is written as:

$$
\begin{aligned}
& \text { Jayakwadi Stage-I (P1) } \\
& \begin{aligned}
\left(1+a_{t}(1, t)\right) \operatorname{RS}(1, t+1)= & \left(1-a_{t}(1, t)\right) \operatorname{RS}(1, t)+\operatorname{IN}(1, t)-\operatorname{HPR}(1, t)-\operatorname{IRR}(1, t) \\
& -\operatorname{IRR}(1, t)-\operatorname{OVF}(1, t)-\operatorname{WSR}(1, t)-F C R(1, t) \\
& +\alpha_{1} \operatorname{HPR}(1, t)-\operatorname{EFR}(1, t)-A_{0} e_{t}(1, t) \\
\forall t= & 1,2,3, \cdots, 12
\end{aligned}
\end{aligned}
$$

Jayakwadi Stage-II (P2) 


$$
\begin{aligned}
\left(1+a_{t}(2, t)\right) \operatorname{RS}(2, t+1)= & \left(1-a_{t}(2, t)\right) \operatorname{RS}(2, t)+\operatorname{IN}(2, t)+\alpha_{2} \operatorname{FCR}(1, t) \\
& -\operatorname{HPR}(2, t)-\operatorname{IRR}(2, t)-\operatorname{OVF}(2, t)-\operatorname{WSR}(2, t) \\
& -\operatorname{EFR}(2, t)-A_{0} e_{t}(1, t) \\
\forall t= & 1,2,3, \cdots, 12
\end{aligned}
$$

Yeldari (P3)

$$
\begin{aligned}
\left(1+a_{t}(3, t)\right) \mathrm{RS}(3, t+1)= & \left(1-a_{t}(3, t)\right) \mathrm{RS}(3, t)+\operatorname{IN}(3, t)-\operatorname{HPR}(3, t) \\
& -\operatorname{OVF}(3, t)-\operatorname{WSR}(3, t)-\operatorname{EFR}(3, t)-A_{0} e_{t}(3, t) \\
\forall t= & 1,2,3, \cdots, 12
\end{aligned}
$$

Jayakwadi Stage-I (P1) is a multipurpose reservoir, constructed for fulfil water availability for Marathwada region. Reservoir supplies water for irrigation also it supplies water for drinking and industrial use to nearby towns and villages and to municipalities and industrial areas in Aurangabad and Jalna districts. Another feature of this project is the bird sanctuary. Many species of birds from all over the country visit the Nathsagar Reservoir created by the dam. The abundance of waterfowl-loving swamps, algae, aquatic plants, small fish, insects and a wide variety of aquatic habitats attract domestic and exotic birds to reservoir. About 200 endemic and about 70 migratory birds of different species are found in the vicinity of this reservoir. Also, more than 50 species of fish are found in Jayakwadi reservoir. Total 183,322 $\mathrm{Ha}$, of command area receives irrigation supply from Jayakwadi Stage-I project through left and right bank canals. Pump storage type hydropower plant of $12 \mathrm{MW}$ capacity is installed at Jayakwadi Stage-I project. Water released through power plant is stored in a pool downstream and pumped back to reservoir. This volume of water is also considered in model with $10 \%$ of transition loss.

Godavari is also an important river in Maharashtra from a religious point of view. Kumbh Mela in Nashik is one of the largest religious events in the world. Millions of devotees from all over the world take holy dip in Godavari water at this moment. Paithan, where the Jayakwadi reservoir was constructed, also hosts a number of Hindu ceremonies throughout the year. Nanded is a very important religious place for Sikhs. All these holy places are situated on the banks of Godavari. Therefore, having a definite uninterrupted environmental flow in the Godavari throughout the year is essential for the devotees in terms of religion as well as health.

Jayakwadi Stage-II (P2) is constructed on Sindaphana river which also receives water from Jayakwadi Stage-I reservoir through feeder canal. The feeder canal release (FCR) from Jayakwadi stage-I is added in model with $10 \%$ transition loss. A canal hydropower plant is also installed at Jayakwadi Stage-II project with capacity of 2.25 MW. Jayakwadi stage-II project irrigates around 93,800 Ha. of area through right bank canal. Yeldari Reservoir (R3) is constructed on Purna river which is a tributary of Godavari. Yeldari project generates hydropower through installed hydropower plant of capacity $15 \mathrm{MW}$ which is purely a hydropower project. Table 2 shows the monthly inflow value and demand of water for hydropower plant for all reservoirs. 
Table 2. Inflow and maximum demand of water for hydropower generation in million cubic meters.

\begin{tabular}{ccccccc}
\hline \multirow{2}{*}{ Month } & $\begin{array}{c}\text { Jayakwadi Stage-I } \\
\text { Hydropower Plant (P1) }\end{array}$ & $\begin{array}{c}\text { Jayakwadi Stage-II } \\
\text { Hydropower Plant (P2) }\end{array}$ & \multicolumn{2}{c}{$\begin{array}{c}\text { Yeldari } \\
\text { Hydropower Plant (P3) }\end{array}$} \\
\cline { 2 - 6 } & Inflow & Demand & Inflow & Demand & Inflow & Demand \\
\hline Jun & 148.76 & 33.96 & 20.98 & 29 & 72.83 & 80 \\
Jul & 408.25 & 33.96 & 43.46 & 29 & 141.09 & 80 \\
Aug & 610.66 & 33.96 & 96.88 & 29 & 200.36 & 80 \\
Sep & 600.00 & 33.96 & 144.17 & 29 & 160.77 & 80 \\
Oct & 287.75 & 33.96 & 75.52 & 29 & 123.1 & 80 \\
Nov & 196.46 & 33.96 & 10.24 & 29 & 49.48 & 80 \\
Dec & 125.53 & 33.96 & 4.27 & 29 & 35.58 & 80 \\
Jan & 37.65 & 33.96 & 0.37 & 29 & 32.18 & 80 \\
Feb & 21.46 & 33.96 & 0.37 & 29 & 24.23 & 80 \\
Mar & 19.56 & 33.96 & 0.16 & 29 & 23.54 & 80 \\
Apr & 25.50 & 33.96 & 0.12 & 29 & 13.15 & 80 \\
May & 46.58 & 33.96 & 0.06 & 29 & 13.86 & 80 \\
\hline
\end{tabular}

\section{Result and Discussion}

Optimal reservoir operation model was developed for maximizing the total annual releases for hydropower generation for multi-reservoir system on monthly operating basis. Developed model provides optimized sustainable multi-reservoir operation policies, which increases the hydropower production and also protects the river ecosystem by providing minimum essential environmental flow throughout the year. Python programming language was used for optimization model development. Latest version of Python 3 was used with an open-source linear programming package PuLP library.

Developed optimization model provides maximum total annual supply for multi-reservoir hydropower generation which is 1503.7362 million cubic meters (MCM). Results from Table 3 show, in case of Jayakwadi Stage-I reservoir release are made available as $100 \%$ of maximum demand for all months. From table 4 it is seen that, at Jayakwadi stage-II releases for hydropower will be $32.50 \%$ and $95.84 \%$ of maximum demand for the month of June and July respectively. From August to April developed model provides hydropower releases to run power plant with full capacity and for May releases available as $97.85 \%$ of maximum demand. Results in Table 5 show, for Yeldari project hydropower release of $79.28 \%$ of maximum demand is available in June. From July to February $100 \%$ demand of power generation was fulfilled by developed model. And for remaining months' supply is available as $42.75 \%, 20 \%, 20 \%$ of maximum demand for March, April and May respectively, shown in Figure 2.

Similarly total annual irrigation releases in Jayakwadi stage I \& II are 622.31 MCM shown in Figure 3. Annual water supply releases are 446.16 MCM made 
Table 3. Releases from Jayakwadi Stage-I reservoir.

\begin{tabular}{cccccccc}
\hline & \multicolumn{5}{c}{ Plant No: -1 Jayakwadi Stage-I } \\
\hline \multirow{2}{*}{ Month } & $\begin{array}{c}\text { Inflow } \\
\text { (MCM) }\end{array}$ & $\begin{array}{c}\text { Evaporation } \\
\text { Loss } \\
\text { (MCM) }\end{array}$ & Spill & Irrigation & $\begin{array}{c}\text { Hydro- } \\
\text { Power }\end{array}$ & $\begin{array}{c}\text { Water } \\
\text { Supply }\end{array}$ & $\begin{array}{c}\text { Environmental } \\
\text { Flow }\end{array}$ \\
\hline Jun & 148.76 & 59.08 & 48.08 & 5.53 & 33.96 & 31.63 & 1.053 \\
Jul & 408.25 & 47.23 & 316.93 & 8.01 & 33.96 & 31.63 & 1.053 \\
Aug & 610.66 & 44.89 & 310.73 & 7.64 & 33.96 & 31.63 & 1.053 \\
Sep & 600 & 52.63 & 0 & 25.68 & 33.96 & 31.63 & 1.053 \\
Oct & 287.75 & 48.87 & 0 & 80.28 & 33.96 & 31.63 & 1.053 \\
Nov & 196.46 & 42.77 & 0 & 68.42 & 33.96 & 31.63 & 1.053 \\
Dec & 125.53 & 32.37 & 0 & 63.23 & 33.96 & 31.63 & 1.053 \\
Jan & 37.65 & 39.72 & 0 & 69.55 & 33.96 & 31.63 & 1.053 \\
Feb & 21.46 & 37.05 & 0 & 25.51 & 33.96 & 31.63 & 1.053 \\
Mar & 19.56 & 75.41 & 0 & 21.02 & 33.96 & 31.63 & 1.053 \\
Apr & 25.5 & 91.79 & 0 & 25.63 & 33.96 & 31.63 & 1.053 \\
May & 46.58 & 79.69 & 0 & 17.44 & 33.96 & 31.63 & 1.053 \\
Annual & 2528.17 & 651.54 & 675.74 & 417.94 & 407.52 & 379.56 & 12.636 \\
\hline
\end{tabular}

Table 4. Releases from Jayakwadi Stage-II reservoir.

\begin{tabular}{cccccccc}
\hline \multicolumn{7}{c}{ Plant No: -2 Jayakwadi Stage-II } \\
\hline Month & $\begin{array}{c}\text { Inflow } \\
(\text { MCM })\end{array}$ & $\begin{array}{c}\text { Evaporation } \\
\text { Loss } \\
\text { (MCM) }\end{array}$ & Spill & Irrigation & $\begin{array}{c}\text { Hydro- } \\
\text { Power }\end{array}$ & $\begin{array}{c}\text { Water } \\
\text { Supply }\end{array}$ & $\begin{array}{c}\text { Environmental } \\
\text { Flow }\end{array}$ \\
\cline { 6 - 8 } Jun & 20.98 & 5.70 & 0 & 2.14 & 9.42 & 3.55 & 0.165 \\
Jul & 43.46 & 5.70 & 0 & 6.25 & 27.79 & 3.55 & 0.165 \\
Aug & 96.88 & 13.88 & 0 & 11.29 & 29 & 3.55 & 0.165 \\
Sep & 144.17 & 19.96 & 0 & 13.81 & 29 & 3.55 & 0.165 \\
Oct & 75.52 & 20.04 & 0 & 39.6 & 29 & 3.55 & 0.165 \\
Nov & 10.24 & 15.50 & 0 & 38.12 & 29 & 3.55 & 0.165 \\
Dec & 4.27 & 12.27 & 0 & 26.83 & 29 & 3.55 & 0.165 \\
Jan & 0.37 & 11.06 & 0 & 30.2 & 29 & 3.55 & 0.165 \\
Feb & 0.37 & 11.49 & 0 & 9.01 & 29 & 3.55 & 0.165 \\
Mar & 0.16 & 8.92 & 0 & 8.69 & 29 & 3.55 & 0.165 \\
Apr & 0.12 & 6.53 & 0 & 10.67 & 29 & 3.55 & 0.165 \\
May & 0.06 & 4.974 & 0 & 7.76 & 28.37 & 3.55 & 0.165 \\
Annual & 396.6 & 136.05 & 0 & 204.37 & 326.59 & 42.6 & 1.98 \\
\hline
\end{tabular}


Water Released for Hydropower Production

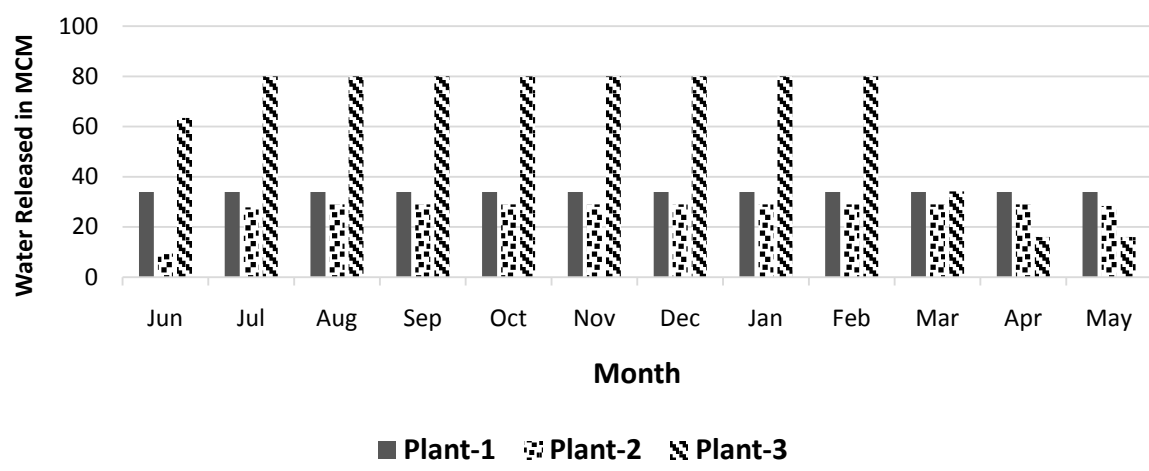

Figure 2. Water releases from each reservoir for hydropower generation in million cubic meters.

\section{Total Releases for Irrigation and Hydro-Power}

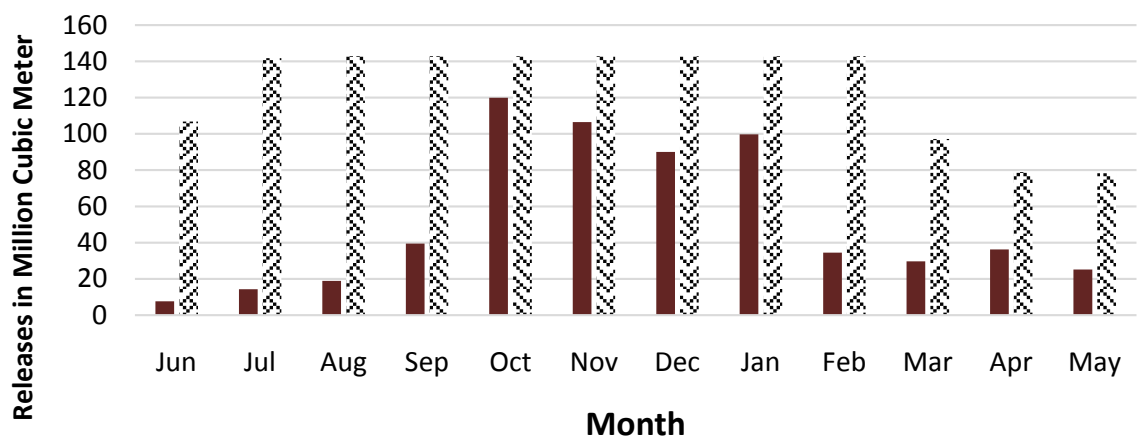

Total Irrigation Releases $\$$ Total Releases for Hydropower

Figure 3. Monthly total water releases from reservoirs for Irrigation and Hydropower generation.

Table 5. Releases from Yeldari reservoir.

\begin{tabular}{cccccccc}
\hline \multicolumn{7}{c}{ Mlant No: -3 Yeldari } \\
\hline Month & $\begin{array}{c}\text { Inflow } \\
(\mathrm{MCM})\end{array}$ & $\begin{array}{c}\text { Evaporation } \\
\text { Loss } \\
\text { (MCM) }\end{array}$ & Spill & Irrigation & $\begin{array}{c}\text { Hydro- } \\
\text { Power }\end{array}$ & $\begin{array}{c}\text { Water } \\
\text { Supply }\end{array}$ & $\begin{array}{c}\text { Environmental } \\
\text { Flow }\end{array}$ \\
\hline Jun & 72.83 & 7.03 & 0 & 0 & 63.42 & 2 & 0.37 \\
Jul & 141.09 & 5.93 & 0 & 0 & 80 & 2 & 0.37 \\
Aug & 200.36 & 7.08 & 0 & 0 & 80 & 2 & 0.37 \\
Sep & 160.77 & 8.34 & 0 & 0 & 80 & 2 & 0.37 \\
Oct & 123.1 & 7.25 & 0 & 0 & 80 & 2 & 0.37 \\
Nov & 49.48 & 5.97 & 0 & 0 & 80 & 2 & 0.37 \\
Dec & 35.58 & 5.55 & 0 & 0 & 80 & 2 & 0.37 \\
Jan & 32.18 & 5.06 & 0 & 0 & 80 & 2 & 0.37 \\
Feb & 24.23 & 7.22 & 0 & 0 & 80 & 2 & 0.37 \\
\hline
\end{tabular}




\section{Continued}

\begin{tabular}{cccccccc}
\hline Mar & 23.54 & 11.08 & 0 & 0 & 34.20 & 2 & 0.37 \\
Apr & 13.15 & 11.74 & 0 & 0 & 16 & 2 & 0.37 \\
May & 13.86 & 9.81 & 0 & 0 & 16 & 2 & 0.37 \\
Annual & 890.17 & 92.10 & 0 & 0 & 769.62 & 24 & 4.44 \\
\hline
\end{tabular}

available from all reservoirs. As a part of sustainable reservoir operation approach annually total $19.075 \mathrm{MCM}$ of environmental flow is also released to sustain the river ecology.

\section{Conclusion}

Maximizing power generation from environmentally friendly power generation projects to meet the rising demand for electricity in the future can be an important option to prevent pollution and global warming. Hydropower projects which generate electricity at low cost and without harming the environment in any way can play an important role in this. An attempt has been made in this study to provide a sustainable solution to meet different water demands of humans with the consideration of environmental water requirement by reservoir optimization. Optimization model provides total annual releases of 1503.7362 million cubic meters for hydropower generation and 622.31 million cubic meters for irrigation. Similarly, annually a total of 19.075 million cubic meters of flow is made available as environmental flow to sustain the river ecology. Water management of the reservoir in this way will definitely help in conserving the river environment and at the same time sustainable development will be achieved.

\section{Acknowledgements}

The authors gratefully acknowledge the Command Area Development Authority, Aurangabad, Maharashtra State, India for providing necessary data for analysis.

\section{Conflicts of Interest}

The authors declare no conflicts of interest regarding the publication of this paper.

\section{References}

[1] Labadie, J.W. (2004) Optimal Operation of Multireservoir Systems: State-of-the-Art Review. Water Resources Planning and Management, 130, 93-111. https://doi.org/10.1061/(ASCE)0733-9496(2004)130:2(93)

[2] Wurbs, R.A. (1993) Reservoir-System Simulation and Optimization Models. Journal of Water Resources Planning and Management, 119, 455-472. https://doi.org/10.1061/(ASCE)0733-9496(1993)119:4(455)

[3] Kim, T., Heo, J.-H., Bae, D.-H. and Kim, J.-H. (2008) Single-Reservoir Operating Rules for a Year Using Multiobjective Genetic Algorithm. Journal of Hydro Infor- 
matics, 10, 163-179. https://doi.org/10.1016/j.jhydrol.2008.04.006

[4] Mousavi, S.J., Ponnambalam, K. and Karray, F. (2005) Reservoir Operation Using a Dynamic Programming Fuzzy Rule-Based Approach. Water Resources Management, 19, 655-672. https://doi.org/10.1007/s11269-005-3275-3

[5] Nagesh Kumar, D., Baliarsingh, F. and Srinivasa Raju, K. (2010) Optimal Reservoir Operation for Flood Control Using Folded Dynamic Programming. Water Resources Management, 24, 1045-1064. https://doi.org/10.1007/s11269-009-9485-3

[6] Chen, H., Yang, L., Yang, Z.F. and Yu, S.W. (2012) Sustainable Reservoir Operations to Balance Upstream Human Needs and Downstream Lake Ecosystem Targets. Procedia Environmental Sciences, 13, 1444-1457. https://doi.org/10.1016/j.proenv.2012.01.136

[7] Regulwar, D.G. and Raj, P. (2009) Multi Objective Multireservoir Optimization in Fuzzy Environment for River Sub Basin Development and Management. Journal of Water Resource and Protection, 1, 271-280. https://doi.org/10.4236/jwarp.2009.14033

[8] Regulwar, D.G. and Kamodkar, R. (2010) Derivation of Multipurpose Single Reservoir Release Policies with Fuzzy Constraints. Journal of Water Resource and Protection, 2, 1030-1041. https://doi.org/10.4236/jwarp.2010.212123

[9] Jager, H.I. and Smith, B.T. (2008) Sustainable Reservoir Operation: Can We Generate Hydropower and Preserve Ecosystem Values? River Research and Applications, 24, 340-352. https://doi.org/10.1002/rra.1069

[10] Yoo, J.-H. (2009) Maximization of Hydropower Generation through the Application of a Linear Programming Model. Journal of Hydrology, 376, 182-187. https://doi.org/10.1016/j.jhydrol.2009.07.026

[11] Arunkumar, V.J. (2012) Optimal Reservoir Operation for Hydropower Generation Using Non-Linear Programming Model. Journal of Institution of Engineers, India, 93, 111-120. https://doi.org/10.1007/s40030-012-0013-8

[12] Morankar, D.V., Raju, K.S. and Kumar, D.N. (2013) Integrated Sustainable Irrigation Planning with Multiobjective Fuzzy Optimization Approach. Water Resources Management, 27, 3981-4004. https://doi.org/10.1007/s11269-013-0391-3

[13] Jothiprakash, V. and Arunkumar, R. (2014) Multi-Reservoir Optimization for Hydropower Production Using NLP Technique. KSCE Journal of Civil Engineering, 18, 344-354. https://doi.org/10.1007/s12205-014-0352-2

[14] Aboutalebi, M., Bozorg Haddad, O. and Loáiciga, H.A. (2015) Optimal Monthly Reservoir Operation Rules for Hydropower Generation Derived with SVR-NSGAII. Journal of Water Resources Planning and Management, 141, Article ID: 04015029. https://doi.org/10.1061/(ASCE)WR.1943-5452.0000553

[15] Ghimire, B.N.S. and Reddy, M.J. (2013) Optimal Reservoir Operation for Hydropower Production Using Particle Swarm Optimization and Sustainability Analysis of Hydropower. ISH Journal of Hydraulic Engineering, 19, 196-210. https://doi.org/10.1080/09715010.2013.796691

[16] Rahimi, H., Ardakani, M.K., Ahmadian, M. and Tang, X.N. (2019) Multi-Reservoir Utilization Planning to Optimize Hydropower Energy and Flood Control Simultaneously. Environmental Processes, 7, 41-52.

https://doi.org/10.1007/s40710-019-00404-8

[17] Brisbane Declaration (2007) The Brisbane Declaration. 10th International River Symposium and International Environmental Flows Conference, Brisbane, 3-6 September 2007, 1-7. 
[18] Jain, S.K. and Kumar, P. (2014) Environmental Flows in India: Towards Sustainable Water Management. Hydrological Sciences Journal, 59, 751-769. https://doi.org/10.1080/02626667.2014.896996

[19] Lokgariwar, C., et al. (2014) Including Cultural Water Requirements in Environmental Flow Assessment: An Example from the Upper Ganga River, India. Water International, 39, 81-96. https://doi.org/10.1080/02508060.2013.863684

[20] Jain, S.K. (2020) Assessment and Implementation of Environmental Flows. Guest Editorial, Current Science, 118, 1011.

[21] CWC, Ministry of Water Resources, Government of India (2007) Report of Central Water Commission Working Group.

[22] Jalansh (2018) Monthly Newsletter of Central Water Commission, Issue No. 4. Water Systems Engineering Directorate Central Water Commission, New Delhi.

[23] (2017) Integrated State Water Plan for Godavari Basin in Maharashtra, Government of Maharashtra Water Resources Department Volume I. 